\title{
Cooperation Among Small Academic Libraries
}

Signs point toward an increasing number of consortia among academic libraries. The knowledge explosion and the sources of support encourage it. A brief study of several regional, state, and local consortia of small college libraries reveals various patterns but many similarities. Enthusiasm for cooperation runs high, but there is a notable lack of evaluation of such efforts. Some are taking irreversible steps as far as their collections are concerned. Positive factors seem to outweigh the negative. Consortia are here to stay.

\section{Brief Overview of Cooperation}

$I$ $\mathrm{N}$ ALL LIKELIHOOD no other aspect of the total library picture has received so much discussion and proportionately so little action as has the subject of cooperation. Certainly there have been some accomplishments, but "it seems characteristic of this aspect of librarianship that for every foot of progress in cooperation there appears a mile of words upon the pages of our library publication." 1 More than thirty years ago the late Carleton B. Joeckel complained that the word "cooperation" was so badly overworked in library writing that he hesitated to use it. ${ }^{2}$ If that was the case in 1936, it must be worn to a frazzle now, for the subject recurs in library lit-

${ }^{1}$ Ralph T. Esterquest, "Co-Operation in Library Services," The Library Quarterly, XXXI (January $1961), 71$.

2 Ibid.

Mr. Lehman is Assistant Librarian in Eastern Mennonite College, Harrisonburg, Virginia. erature with almost clock-like regularity.

Is it because librarians are so unimaginative that they rely upon "cooperation" as a crutch? Has cooperation among libraries, as Ralph Munn indicates, become a sacred concept like motherhood and the flag? ${ }^{3} \mathrm{Or}$ is it because cooperation has become "so intertwined with librarianship itself that judgments about cooperative endeavors often become judgments about fundamental principles of library service?"4

One rather suspects that among the many revolutions occurring in the library world, cooperation is taking its place alongside others. No doubt this revolution began much earlier and continues to move more slowly than say, the computer revolution. Institutional pride does not always make way for thoroughgoing programs of cooperation among academic libraries. Most would agree that it takes a great deal of discussion to make a little progress. Perhaps it

\footnotetext{
${ }^{3}$ Ralph Munn, "Planning for Cooperation," ALA Bulletin, LVIII (June 1964), 496.

'Esterquest, op. cit., 71.
} 
would help to select different words to express the idea of cooperation. Stephen A. McCarthy suggests "library interaction and interdependence" as a possibility. ${ }^{5}$

Cooperation is already so much a part of us that we tend to overlook how pervasive it is. From interlibrary loans, to Library of Congress cards, to welcoming visiting scholars, we collaborate. The question is no longer whether to cooperate but to what degree.

Historically, cooperation has been around a long time and has manifested itself in the making of union catalogs. As early as 1410 the monk John Boston deBury, in his Catalog Scriptorum Ecclesiae, attempted a union catalog. ${ }^{6}$ In the early 1940s Robert Downs counted 117 national, state, regional, and local union catalogs (including fifty-nine Library of Congress Depository Catalogs) in the United States. ${ }^{7}$ Other aspects of cooperation have been thoroughly documented. A simple listing of major cooperative efforts that have been undertaken through the years will suffice for our purposes. The list primarily relates to academic libraries.

1. Union catalogs-from national to local.

2. Bibliographic centers-Denver, Seattle, and Philadelphia, among many others.

3. Cooperative storage-Center for Research Libraries (formerly Midwest Inter-Library Center).

4. Cooperative acquisitions-Farmington Plan.

5. Cooperative cataloging-Library of Congress.

stephen A. McCarthy, "Library Interaction and Interdependence," University of Tennessee Library Lectures, Thomas T. Rogers, ed. (Knoxville: University of Tennessee, 1966), p. 23.

- Yadwiga Kuncaitis, Union Catalogs and Bibliographic Centers: A State-of-the-Art Review (Columbus: The State Library of Ohio, 1968), p. 7.

'Union Catalogs in the United States, Robert B. Downs, ed. (Chicago: American Library Association, 1942 ), p. 351 .
6. Production of bibliographical tools -book catalogs.

7. Cooperative photographic projects -University Microfilms.

8. Cooperation with other types of libraries.

9. Professional conferring-formally and informally, through associations.

10. Resources surveys.

11. Interlibrary loan.

12. Sharing building plans.

13. Combining of academic librariesClaremont, California.

14. Regional, state, and local consortia. ${ }^{8}$

Part of the problem of understanding cooperation as it exists today is the literature written about it. Cooperative projects, particularly consortia, seldom follow established patterns, and they are not always described with scrupulous accuracy. The tendency to place high intrinsic value on cooperation for its own sake discourages objective evaluation. ${ }^{9}$ Far too much of the literature either expounds upon the great possibilities for cooperation or outlines with magnificent detail what a consortium intends to accomplish. Too few define clearly what progress has been made, what the price tag is, what limits there are, and where the point of diminishing returns is to be found. Admittedly, some of these are hard questions but they need answering. Careful analysis of present practices may be uncomfortable but therein lies the road to improvement.

One gets the impression that some academic libraries find it so much more reassuring (and less time-consuming) to continue convincing themselves that

\footnotetext{
${ }^{8}$ Cf., William H. Carlson, "Cooperation: An Historical Review and a Forecast," CRL, XIII (January 1952), 5-13; Esterquest, op. cit., 78-79; McCarthy, op. cit., p. 23-26; Edward B. Stanford, "Increasing Library Resources Through Cooperation," Library Trends, VI (January 1958), 296-308; Eileen Thornton, "Cooperation Among Colleges," Library Trends, VI (January 1958), 309-25; Louis Round Wilson and Maurice F. Tauber, The University Library (2d ed.; New York: Columbia University Press, 1956), p. 44980.

${ }^{\circ}$ Esterquest, op. cit., 71-72.
} 
their limited budgets are being put to the best use possible. Since libraries have traditionally been regarded as service organizations, they have been slow to introduce systems analysis and cost accounting procedures. Consequently, there are few accurate pictures of the costs of individual library operations. ${ }^{10}$ This is doubly true of the costs of cooperation.

The signs point toward increasing cooperation among academic libraries in the future. The Donne paraphrase, "No library is an island unto itself" is seen to contain more and more truth with the passing of time. One eloquent proponent of cooperation put it this way:

For even the casual reader of professional library publications, it should be increasingly evident that the time is ripe for some realistic thoughts-that is, hard-nosed let'sget-down-to-business thoughts-about cooperation. The volume of publications, the increasing costs of acquisitions plus the labor to cope with them, together with the complexity occasioned by broader services and growing constituencies all make it apparent that the library which refuses to consider workable alternatives, such as pooling of effort, is falling hopelessly behind. . . The time is not just ripe for cooperation, it compels it. ${ }^{11}$

The knowledge explosion revolution has posed formidable problems to the academic library, particularly the small college library. Estimates of the explosion are interesting, although one should remember that they are only estimates. Knowledge was said to have doubled from A.D. 1 to 1750 , doubled again by 1900 , again by 1950 , and once more by 1960. Some experts believe that by 1967 it had doubled again. More than 2,000 pages of books, newspapers, or reports come off the worldwide press every six-

\footnotetext{
${ }^{10}$ Joseph Becker and Robert M. Hayes, Information Storage and Retrieval: Tools, Elements, Theories (New York: John Wiley \& Sons, Inc., 1963), p. 39.

${ }_{11}$ James H. Richards, Jr., "Academic Library Cooperation, a Preliminary Report," Minnesota Libraries, XXI (June 1965), 154.
}

ty seconds-the equivalent of seven complete sets of encyclopedias every day. While the United States is annually producing over 30,000 new books, titles, or new editions, the world's annual production of books has been estimated at 320,000 separate titles. These are in addition to 33,000 newspapers, 70,000 periodicals, and millions of research reports, not to mention nearly 100,000 scientific and technical journals being published in more than sixty languages with new journals being born at the rate of two per day. ${ }^{12}$ Adding to the above, the significant outpouring of the new media further complicates the magnitude of the problem of selection, acquiring, storing, and circulating just a small fraction of the best produced. One wonders what the wise Solomon's comment would be today. Nearly ten centuries before Christ he wrote, "Of making many books there is no end."13

Increased impetus toward cooperation by academic libraries comes also from the greater demand for services, as well as from the sources of supportfoundation and government grants, which particularly encourage consortia and other cooperative ventures. "Thus the magnitude of the problem, and the agencies from which support must be obtained, plus the demands for service from readers, all augur a future in which there will be increasing need for libraries to work closely together in ways which they cannot now foresee."14

What does all this mean for the small college library? Ralph H. Parker feels that small libraries in their present state are doomed. Just as technology is destroying the small town, the one-room school house, and the small grocer, so it is going to affect the small library. He

\footnotetext{
12 John G. Lorenz, "The Communication Network: The Academic Library and the Dissemination of Knowledge," Dedication of the University Library (Bowling Green, Ohio: Bowling Green University, 1967 ), p. 19.

13 Ecclesiastes 12:12.

14 McCarthy, op. cit., p. 35.
} 
believes that we are in a transition period in which one of three things will happen to small libraries:

1. Small libraries will become large as small colleges become universities.

2. Libraries will combine. Public libraries more obviously reflect this trend, but look at the Joint University Libraries of Nashville or the Honnold Library, Claremont, California, serving the Associated Colleges of that city.

3. Libraries will cooperate with each other. A national bibliographic network is emerging, in which small and large libraries can receive bibliographic citations instantaneously on a television screen as well as hard copy from books and periodicals via this network within minutes. ${ }^{15}$

It is easy to overestimate what can be done in one year and underestimate what can be done in ten, but we may as well be realistic enough to expect major changes. ${ }^{16}$ Perhaps the prospects for survival of small libraries will be in proportion to their willingness to cooperate.

\section{Characteristics of Regional, State, and Local Consortia}

In the earlier list of fourteen manifestations of cooperation among academic libraries we included consortia. Mounting evidence points toward the increasing proliferation of such cooperative ventures among colleges. To mention a few of recent origin, one could name the Arkansas Foundation of Associated Colleges (AFAC), begun in 1954; the Associated Colleges of the Midwest (ACM), formed in 1959; the Great Lakes Colleges Association (GLCA), incorporated in 1961; the Area College Library Cooperative Program of Central Penn-

\footnotetext{
${ }^{15}$ Ralph H. Parker, "The Small Library Faces the Future," ALA Bulletin (June 1967), 669-71.

${ }^{16}$ Carl F. J. Overhage and R. Joyce Harman, Intrex, Report of a Planning Conference on Information Transfer Experiments (Cambridge, Mass.: M.I.T., 1965 ), p. 43.
}

sylvania (ACLCP), originating in September 1965; LIBRAS, which organized in December $1965 .{ }^{17}$

In some cases cooperation among member libraries represents only one facet of a broader program of cooperation among the colleges. Cooperation on other levels sometimes preceded library cooperation. The ACM for example, did not begin significant library cooperation until a decade after its origin. In other cases (LIBRAS, ACLCP) interest in library cooperation was the prime factor in establishing the consortium.

Certain patterns of cooperation emerge. Interest in improving interlibrary loan systems has prompted many colleges to enter into cooperative ventures. Procedures become streamlined. In some cases union catalogs are compiled. Some groups which produce a union catalog of periodical holdings also discover it to be more difficult to find time and money to invest in a union catalog of books. AFAC exchanged some book cards for a period of time but has now discontinued it for lack of money, not because it was not helpful. ${ }^{18}$ LIBRAS is currently constructing a union card catalog of current book purchases. ${ }^{19}$ Union lists of periodicals, in

${ }^{17}$ AFAC: A state consortium including the following colleges: Arkansas, College of the Ozarks, Harding, Hendrix, John Brown University, Ouachita Baptist University, and Southern Baptist Junior College; ACM: Regional group including ten colleges in Illinois, Iowa, Minnesota, and Wisconsin: Beloit, Carleton, Coe, Cornell, Grinnell, Knox, Lawrence, Monmouth, Ripon, St. Olaf.; GLCA: Regional consortium of colleges in Ohio, Indiana, and Michigan: Albion, Antioch, Denison, DePauw, Earlham, Hope, Kalamazoo, Kenyon, Ohio Wesleyan, Oberlin, Wabash, and Wooster; ACLCP: Local venture of twelve colleges and the Pennsylvania State Library. Colleges include Capital Campus of Pennsylvania State University, Dickinson, Elizabethtown, Franklin and Marshall, Gettysburg, Harrisburg Area Community College, Juniata, Messiah, Millersville State, Shippensburg State, Wilson, York Junior; LIBRAS: Local consortium of eight colleges in the west suburban Chicago area: Aurora, Elmhurst, George Williams, Maryknoll, North Central, St. Dominic, St. Procopius, Wheaton.

1s Telephone interview with Shirley Birdsall, Librarian, Harding College, Searcy, Arkansas, November $27,1968$.

19 Letter from Marilyn T. Thompson, Librarian, George Williams College, Downers Grove, Illinois, November 15, 1968. 
some cases, are updated annually (ACLCP); in other cases as many as five years elapse between updatings (AFAC). ACLCP compiled some union lists of special collections but found them of uneven usefulness, depending upon curricular interests of participating colleges. $^{20}$ Telephone service and free photocopying facilitate interlibrary loan in many consortia.

Sharing within a consortium often occurs on various levels. Members of a group often exchange acquisition lists, subject bibliographies, library bulletins (including "house organs" such as GLCA Librarian's Newsletter) and other memos. Librarians participating in consortia universally agree that the contact with other librarians in their periodic meetings, whether monthly (LIBRAS), quarterly (ACLCP), or annually (AFAC), is in itself one of the most significant benefits. Not all are as candid, however, in evaluating cooperation and the place of discussion, as is Russell F. Barnes.

I suppose the best general statement I could use to describe cooperation among Twin City academic libraries would be to say that we spend more time talking about cooperating than we do cooperating. The talk is helpful though, it keeps us acquainted with what we are doing individually and makes it a simple matter to call someone on the telephone and ask a favor, and this is essentially what cooperation amounts to-helping one another. ${ }^{21}$

A highly significant but somewhat irreversible feature of some consortia is the development of subject specializations. Member colleges agree on intensive development of holdings in certain subject areas. Therein lies the key to a small college gaining ready access to a

${ }^{20}$ Area College Library Cooperative Program South Central Pennsylvania, Score Sheet of Progress: 19651967, November 1967, 1-2.

21 Letter from Russell F. Barnes, Librarian, James Jerome Hill Reference Library, Saint Paul, Minnesota, November 12, 1968. far more sophisticated collection than it could afford on its own. Thereby they sacrifice, to some extent, a well-rounded though small collection in all subjects. Thorough pursuance of this type of specialization demands a permanent commitment to participation in the consortium. Subject specialization carries a price; librarians here usually consider the future carefully before advancing too far too fast. AFAC has engaged in subject specialization for over ten years -long enough that a few individuals have become a bit uneasy on the question, fearing that collections are becoming too specialized for a small liberal arts college. ${ }^{22}$

One unique venture in cooperation is the Periodical Bank established in early 1969 by ACM. Patterned somewhat after the cooperative storage program of the Center for Research Libraries on the graduate level, this undergraduate program breaks new ground. Member libraries gave up about 15 per cent of their periodical collection, either in complete runs of titles or in runs up to the last five or ten years. Each college sent $\$ 50,000$ worth of materials to the central Bank (located in Newberry Library in Chicago with the main ACM offices). Materials remain either on paper or are put on film, from which printouts are made. The Bank holds only one set each of about 2,000 titles. These are neither esoteric and impractical items nor, for obvious reasons, the most heavily used periodicals. Connections with member libraries through teletype provides sameday service on any desired item. ${ }^{23}$

ACM colleges initiated this plan to reduce current periodical subscriptions in

2 Robert B. Downs, Report on a Survey of the Libraries of the Arkansas Foundation of Associated Colleges (Little Rock: Arkansas Foundation of Associated Colleges, 1963), p. 3-4.

${ }_{23}$ Telephone interview with James H. Richards, Jr., Librarian, Carleton College, Northfield, Minnesota, November 27, 1968, and letter from Richard A. Lyders, Director, Associated Colleges of the Midwest, Chicago, Illinois, December 2, 1968. 
individual member libraries to a minimum, as well as to keep from being interlibrary loan parasites to large universities. Disadvantages include the time lag in obtaining hard copy and the fact that browsing among these periodicals is eliminated. ${ }^{24}$ Most significant is the irreversible nature of this venture. Other colleges will certainly await further word from this cooperative venture to see what time, experience, and evaluation have to say.

A consortium encourages member colleges to become more uniform in their library service and their approach to library procedures. Thus, for example, nine of the twelve members of GLCA changed from Dewey to LC as a result of two conferences on reclassification. ${ }^{25}$ In several cases (LIBRAS, ACLCP) direct-borrowing privileges of undergraduate students among member libraries have been facilitated.

\section{Summary}

The viable examples of cooperation among small colleges suggest a number of generalizations. Each consortium approaches cooperation differently. While there are many similarities, the differences stand out in bold relief. No standard pattern fits. This is to be expected since no two colleges have the same philosophy and objectives, the same geographical situation, and other factors that bear upon cooperation. Others, therefore, who may be considering the formation of a consortium, have a variety of patterns that could serve as a model.

Those participating in a consortium are enthusiastic about cooperation. Generally they advocate more and more cooperation but no one seems to have

\footnotetext{
${ }^{24}$ James H. Richards, Jr., "ACM Service LibraryPeriodical Bank," The Voice, XXXIII (May 1968), 20. ${ }^{25}$ James E. Gaines, "Reclassification in the Libraries of the Great Lakes Colleges Association," CRL, XXIX (July 1968), 292-93.
}

given much thought how far to go with it, or at what point to begin to level off. There seems to be little tendency to evaluate present levels of cooperation before more is encouraged. There is a notable lack of information on what the true costs are; most expenses seem to be absorbed into the regular budget and little or no regard is given to isolating the true costs. Most are concerned that the libraries in the consortium are similar in many respects; in other words, they are usually not eager to welcome too many junior colleges or libraries considerably weaker than the average. Librarians are happy that participation in cooperative ventures strengthens their hand in obtaining grants from foundations and government agencies. Appearances indicate that cooperation encourages libraries individually to strengthen their collections in addition to and from the benefits that accrue from the consortium. Participants feel that the time and expense is well worth it, and that they are providing better service to patrons, thereby making a significant contribution to a liberal arts education.

Is library cooperation a panacea or a pitfall? Probably neither if pursued creatively and geared to the local situation. Nor should it be rushed into too hastily lest expensive mistakes be made. The problems are complex because academic libraries are parts of complex institutions. Cooperation involves certain compromises and may affect institutional pride. These factors must be explored and understood carefully. The entire library staff, the administration, and the faculty must be sold on the idea of entering into a consortium before it is attempted. Nelson, Logsdon, and Adams have summarized succinctly the various factors involved in library cooperation:

1. Cooperation is desirable when it benefits the institutions individually 
or makes them more effective collectively.

2. Each participating institution in a cooperative venture must benefit.

3. Cooperation must be a voluntary act.

4. Benefits cannot always be assured in advance.

5. Objective appraisal of results is as critical as advance planning and sound implementation.

6. Cooperation must take into account the legitimate ambitions and present status of individual institutions. A degree of rivalry and competition among institutions is to be expected.

7. Cooperation must not impose uniformities that destroy the special character of individual institutions.

8. Conversely, where economies and benefits can be achieved through cooperation without destroying the special character of institutions, they are not to be feared.

9. No institution is so rich in resources that it can be assumed to have nothing to gain by cooperation.

10. The support of top leaders in each institution is essential.
11. The cooperative effort must be professionally staffed.

12. Cooperation is a means not an end.

13. Effective broad sharing on a comprehensive scale is possible only through a systems approach.

14. An adequate governmental structure must be developed and sustained. ${ }^{26}$

It would seem that by following this advice and learning from the experiences of existing consortia, cooperation among small academic libraries should increase significantly in years to come.

At this point we have moved only a little from the vantage point described by Ralph Ellsworth nearly twenty years ago upon the dedication of the Midwest Inter-Library Center (now Center for Research Libraries). "We are like mountain climbers in unexplored territory, who, at great cost, gain one peak, only to discover that it is merely a shoulder to another distant, higher, and more formidable range." 27

${ }^{26}$ Charles A. Nelson, Dr. Richard H. Logsdon, and Scott Adams, "Library Cooperation: Panacea or Pitfall?" Special Libraries (October 1965), 571-74.

${ }^{27}$ Ralph E. Ellsworth, "Tasks of the Immediate Future," The Library Quarterly, XXII (January 1952), 18. 